\title{
COMPARATIVE STUDY OF WATER QUALITY OF DIFFERENT LAKES IN CHENNAI
}

\author{
P. K. Raji ${ }^{1, *}$ and Marykutty Abraham ${ }^{2}$ \\ ${ }^{1}$ Assistant Professor, Sathyabhama University, Tamilnadu , Chennai-600 119 \\ ${ }^{2}$ Scientist E, Sathyabama University, Tamilnadu, Chennai-600 119 \\ *E-mail: rajipk72@gmail.com
}

\begin{abstract}
Water quality in lakes is subjected to the natural degradation process of eutrophication and has adverse impact on societal development. Most of the lakes in Chennai shrunk considerably due to the aggressive rapid urbanization process and uncontrollable encroachment. Urban push of expansion and pollution decreased the potability of water. By consuming the contaminated water, people living in the neighborhood prone to contact water-borne diseases. It is therefore essential to monitor the lake water quality at regular intervals of time. This study aims at assessing the water quality of various lakes in and around Chennai city. A detailed survey was conducted to study some physicochemical, biological parameters of the six major lakes of Chennai. Water samples from the lakes were collected and analysis was carried out on the parameters such as pH, Total Hardness, Biological Oxygen Demand, Chemical Oxygen Demand, Total Nitrogen, Total Phosphorus, and E coli. The ranges of various parameters obtained are $\mathrm{pH}$ (6-8.7), BOD (9-34mg/l), COD (13-102 mg/l), and TP (0.02-0.162 mg/l), TN (0.4- 2.4 mg/l), TDS(386-2280), and E coli (34-900, N/100 ml) for the various lakes under study. An assessment of lake water quality was done for domestic use by water quality index (WQI) also. The studies reveal that some analytical aspects are higher than the prescribed limit by the WHO and BIS standard. This analytical study would enhance the socio eco features of these water bodies by implementing utility based restoration and development programmes. Systematic and periodical awareness camps may be organized to induce and encourage the local public to maintain the ecology and hydrology of the lakes.
\end{abstract}

Keywords: Bio chemical oxygen demand, E coli, Water quality index, Pollution

(C) RASĀYAN. All rights reserved

\section{INTRODUCTION}

Rapid industrialization around lakes, tanks, and other water bodies became irresistible due to various anthropogenic compulsions resulting in gradual deterioration of the water bodies. Encroachment and pollution aggravated the degradation of water by letting domestic wastewater, industrial effluents, dumping of solid waste and negligence face the lake causing considerable reduction in the surface water quality. The rural and suburban lakes were subjected to the invasive and aggressive burden of expansions. Therefore water pollution is a serious threat to the human population. The cities like Chennai facing acute shortage of water. So, as a safety measure, a monitoring program that will provide a representative and reliable estimation of the quality of surface waters is necessary. Thus, monitoring programs including frequent water sampling at various locations and determination of physicochemical parameters are carried out. As the need of water supply to Chennai city, Tamil Nadu is expected to raise as 2100 million liters per day, the government authorities need to design a proper water management system. Restoration of our valuable water bodies is one among the prime component of water management. So this study aimed to compare the quality parameters of various lakes of Chennai. And also the significance of pollutants in the surface water bodies.

\section{EXPERIMENTAL}

\section{Study Area}

The lakes for the study are selected from an urban area, peri-urban area and from Chennai city. Most of such lakes are under constant encroachment and pollution due to the dumping of waste. Porurlake (200 acres), Perungudi lake (50 acres), Velachery lake (100 acres), Nandhivaramlake (850acres) and 
Karapakkam lake (518acres) is the considered study areas. The Fig.-1 shows the map of the location of the selected lakes in Chennai. The samples from the above lakes were collected at the same duration.

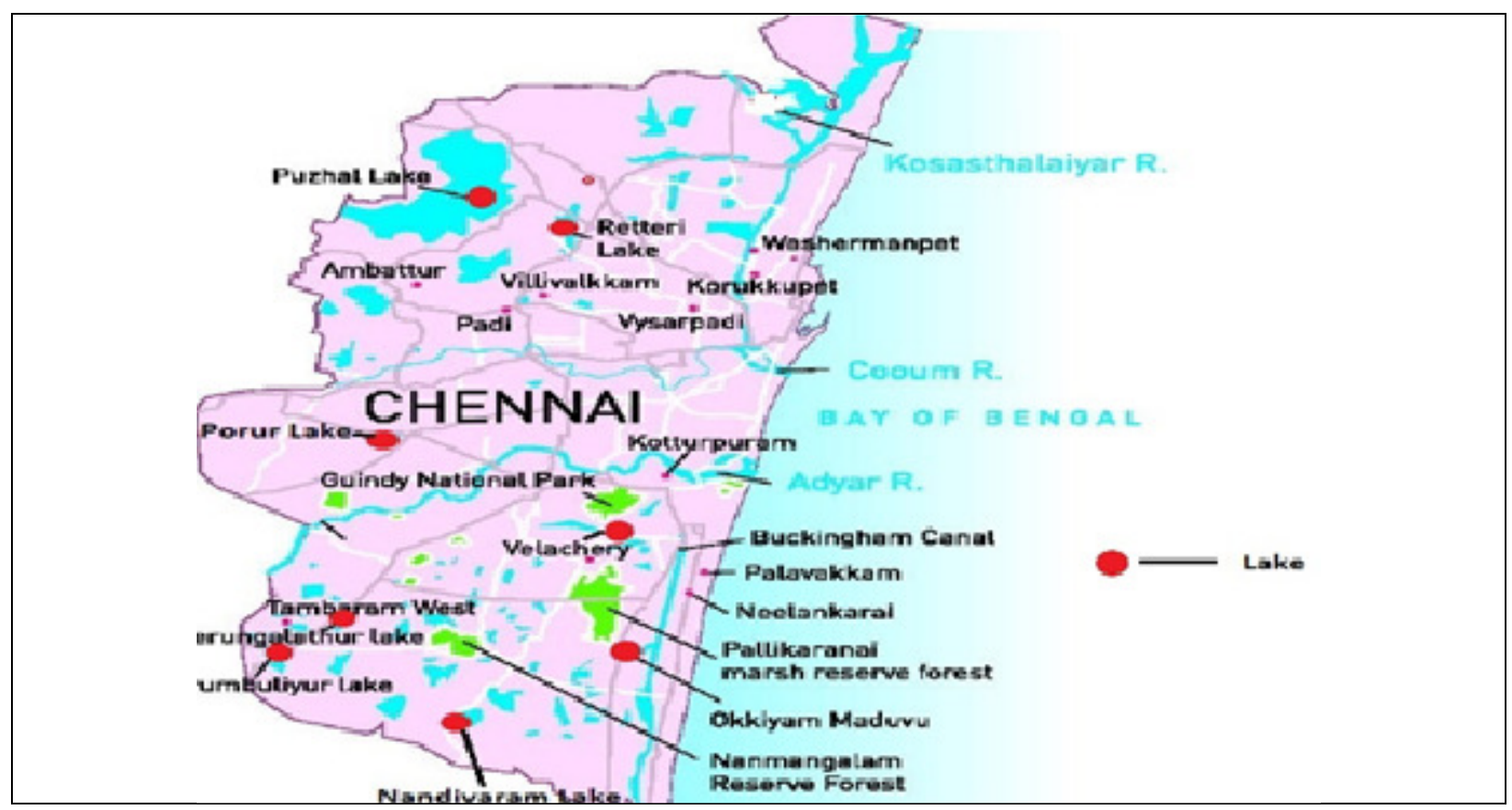

Fig.-1: Map showing the locations of Lakes in and around Chennai, India

\section{Sampling and Analysis}

Samples were taken in three different locations in each lake and mixed to get a composite sample. The standard sampling procedure has followed and the parameters like $\mathrm{pH}, \mathrm{BOD}, \mathrm{COD}, \mathrm{TDS}, \mathrm{TP}, \mathrm{TN}$ and $\mathrm{E}$ Coli were analyzed. The methods of analysis for the various parameters are shown in Table-1.

Table-1: Different parameters with their analytical technique and surface water quality guideline values as per who and Indian standard.

\begin{tabular}{|c|c|c|c|c|c|}
\hline S.No. & Parameters & Technique used & WHO & Indian & EPA \\
\hline 1 & $\mathrm{pH}$ & $\mathrm{pH}$ meter & $6.5-9.5$ & $6.5-9.5$ & $6.5-9.5$ \\
\hline 2 & BOD mg/l & $\begin{array}{l}\text { Incubation } \\
\text { followed by } \\
\text { titration }\end{array}$ & 6 & 3 & 5 \\
\hline 3 & $\mathrm{COD} \mathrm{mg} / \mathrm{l}$ & COD digester & 10 & - & 40 \\
\hline 4 & $\mathrm{TN} \mathrm{mg} / \mathrm{l}$ & $\begin{array}{c}\text { UV } \\
\text { Spectrophoto } \\
\text { meter }\end{array}$ & 3 & 45 & .5 \\
\hline 5 & $\mathrm{TP} \mathrm{mg} / \mathrm{l}$ & $\begin{array}{c}\text { Digestion and } \\
\text { colorimeter }\end{array}$ & - & - & .124 \\
\hline 6 & TDS mg/l & $\begin{array}{c}\text { Gravimetric } \\
\text { method }\end{array}$ & 500 & 500 & - \\
\hline 7 & $\begin{array}{c}\text { E coli } \\
\mathrm{N} / 100 \mathrm{ml}\end{array}$ & $\begin{array}{l}\text { Membrane } \\
\text { filtration } \\
\text { technique }\end{array}$ & - & - & 1000 \\
\hline
\end{tabular}

\section{RESULTS AND DISCUSSION}

The summary of values of different parameters of lake water is given in the Table-2. The higher values of parameters are linked with some particular pollution in the corresponding catchment and lake 
surroundings. The concentration levels of the seven parameters in the lakes under study are shown in the Fig.-2 to Fig.-7.

Table-2: Water Quality Parameters of Different Lakes

\begin{tabular}{c|c|c|c|c|c|c}
\hline Parameters & $\begin{array}{c}\text { Perungudi } \\
\text { L1 }\end{array}$ & $\begin{array}{c}\text { Porur } \\
\text { L2 }\end{array}$ & $\begin{array}{c}\text { Puzhal } \\
\text { L3 }\end{array}$ & $\begin{array}{c}\text { karapakkam } \\
\text { L4 }\end{array}$ & $\begin{array}{c}\text { Velachery } \\
\text { L5 }\end{array}$ & $\begin{array}{c}\text { Nandhivaram } \\
\text { L6 }\end{array}$ \\
\hline $\mathrm{pHpH}$ & 6 & 6.2 & 7 & 6.1 & 8.87 & 7.02 \\
\hline BOD5 mg/l & 20 & 12 & 14 & 21 & 34 & 9 \\
\hline $\mathrm{COD} \mathrm{mg/l}$ & 58 & 34 & 19 & 21 & 102 & 12.8 \\
\hline $\mathrm{TDS} \mathrm{mg/l}$ & 386 & 568 & 350 & 380 & 2280 & 443 \\
\hline $\mathrm{TN} \mathrm{mg/l}$ & 1.6 & 1.4 & 1.14 & 0.7 & 2.4 & 0.4 \\
\hline $\mathrm{TP} \mathrm{mg} / \mathrm{lmg} / 1$ & 0.02 & 0.03 & 0.02 & 0.03 & 0.162 & 0.126 \\
\hline Ecoli,N/100ml/100ml & 136 & 900 & 300 & 34 & 342 & 212 \\
\hline
\end{tabular}

\section{pH}

The assessed values of $\mathrm{pH}$ in the selected lakes are illustrated in a graph with the permissible upper range of $\mathrm{pH}$ (8.5). Due to surface runoff, domestic waste, and dumping of construction demolition wastes the $\mathrm{pH}$ of Velachery lake(L5) exceeds the permissible limit. The values show excessive alkalinity, with organoleptic consequences. The $\mathrm{pH}$ value at the range of 5.0-9.0 is suitable for fisheries, though 6.5-8.5 is preferable for drinking purpose. ${ }^{8}$ The values of $\mathrm{pH}$ in selected lakes are shown in the Fig. -2 .

\section{Bio-Chemical Oxygen Demand (BOD)}

BOD indicates the amount of organic contaminants in the water, which inturn affects the amount of dissolved oxygen. Dissolved oxygen is one of the most important characteristics of water which affects the growth of any aquatic organisms. Current studies say that $5 \mathrm{mg} / \mathrm{l}$ is the minimum requirement for tropical freshwater fish even though some fish species tolerate $3 \mathrm{mg} / \mathrm{l}$. As per the Indian Standards for surface water quality (Class $A, B \& C$ ) the permissible value for BOD is $3 \mathrm{mg} / \mathrm{l} .{ }^{11}$ This study reveals the concentration of BOD exceeds the permissible limit in all the lakes which confirms that water can be used only for irrigation and industrial activity. The presence of BOD in various lakes is shown in the Fig.-3.

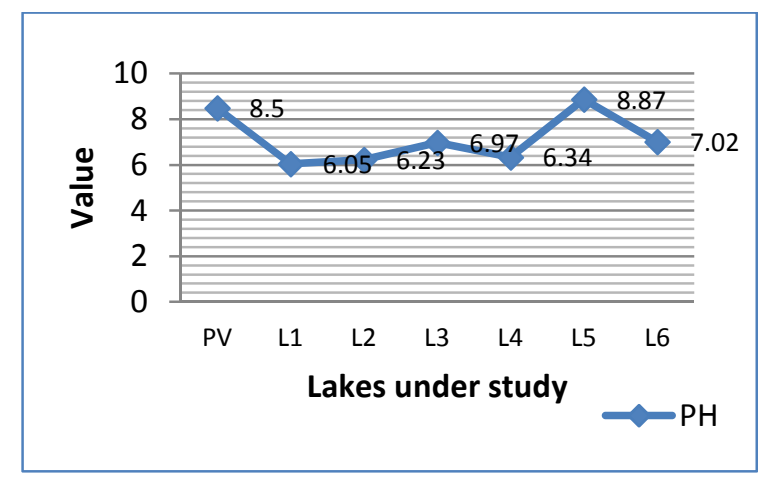

Fig.-2: Variation of $\mathrm{pH}$ in all Selected Lakes

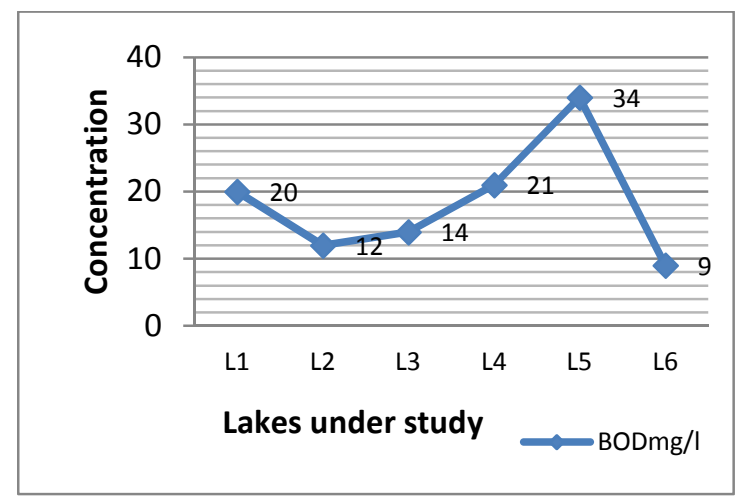

Fig.-3: The Values of BOD in the Lakes.

\section{Chemical Oxygen Demand (COD)}

COD measures the chemically oxidizable organic matter in water. Like BOD, Chemical oxygen demand is also the indicator of the healthy lake ecosystem. The concentrations of COD in the six lakes are shown in the Fig.-4.

\section{Total Dissolved Solids (TDS)}

The runoff, letting of sewage and industrial effluents into the lake lead to the increased level of total dissolved solids in the lake water. This analysis shows that TDS value ranges between 386 to $2280 \mathrm{mg} / \mathrm{l}$. The authorities are taking steps to reduce the high TDS level which is greater than $2100 \mathrm{mg} / \mathrm{l}$ that is the 
acceptable level of class E(irrigation purposes) water. Presence of TDS in various lakes is shown in the Fig.-5.

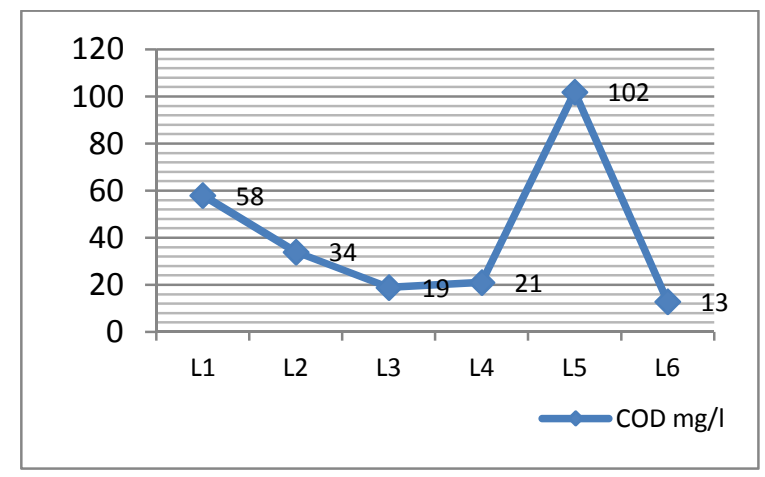

Fig.-4: Variation of COD in all selected Lakes

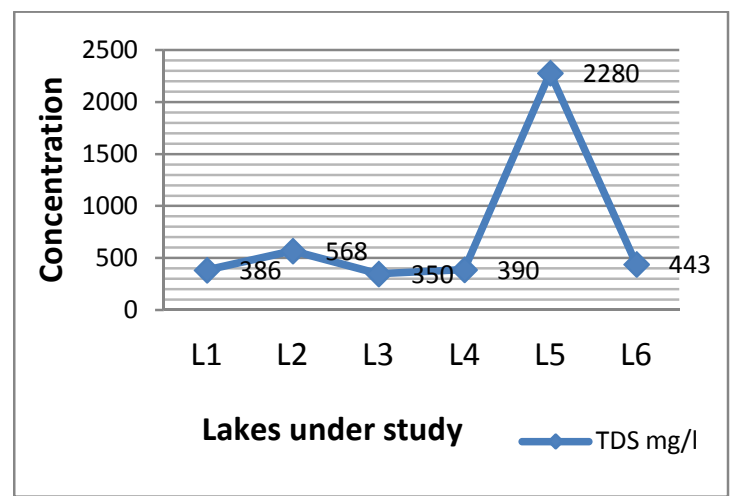

Fig.-5: The values of TDS in the Lakes

\section{Total Nitrogen $(\mathrm{TN})$}

Nitrogen in lake water has been found to be one among the prominent nutrients which lead to eutrophication. Nitrogen can enter lakes by urban runoff, effluents from sewage treatment plants and from sediments. To identify the water bodies under risk and reduce the effect of eutrophication, the US EPA developed guidelines, which recommends the permissible limit for nitrogen as $0.3 \mathrm{mg} / \mathrm{l}$ for streams and $0.1 \mathrm{mg} / \mathrm{l}$ in lakes. ${ }^{8} \mathrm{In}$ the present study it is observed that the minimum TN value is $0.4 \mathrm{mg} / \mathrm{l}$ in Nandhivaram lake and the maximum is $2.4 \mathrm{mg} / \mathrm{l}$ in Velachery lake. So we can understand that some of the lake waters under study are suitable for industrial and agricultural purposes and not for direct consumption. The concentrations of total Nitrogen in the selected six lakes are shown in the Fig.-6.

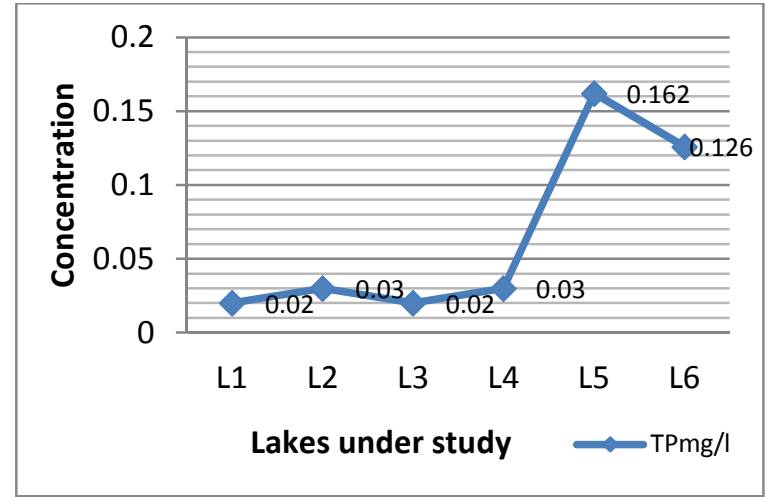

Fig.-6: The Concentration of Total phosphorus in the Lakes

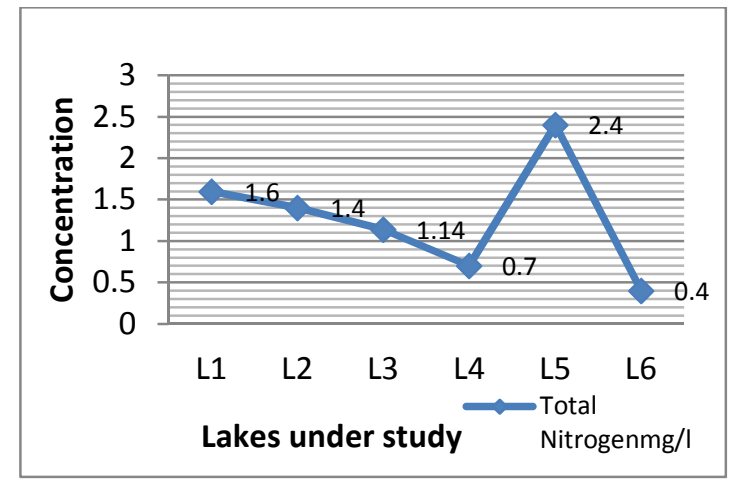

Fig.-7: The concentration of Total Nitrogen in the Lakes

\section{Total Phosphorus (TP)}

Phosphorus is a limiting nutrient which controls the growth of algae in lakes. Fertilizers, human and animal wastes, detergents are the sources of Phosphorus. In the case of phosphorus, it is often tried to reduce the phosphorus input into lakes. Soluble reactive phosphorus (SRP)is dissolved phosphorus readily usable by algae. Total phosphorus is the sum of dissolved and particulate forms of phosphorus. TP concentrations exceeding $0.03 \mathrm{mg} / \mathrm{l}$ can cause eutrophication in lakes ${ }^{2}$. The analysis showed that the range of TP was from0.02 to $0.162 \mathrm{mg} / \mathrm{l}$. Industrial activities and heavy sewage disposal increased the phosphorus level in Velachery lake water. Likewise due to the increased social development and also many small-scale industries, agricultural activity Nandhivaram lake water also tends to get accumulated by phosphorus loadings recently and has been elevated as a eutrophic lake. The total phosphorus in various lake water samples are determined in the laboratory and the values are shown in theFig. -7 . 


\section{E. coli}

The presence of high concentration of E. coli (Escherichia coli) indicates strong, recent pollution by human and animal waste. These bacteria are of fecal origin (human and animal) and they are excreted in huge numbers. The presence of pathogens is confirmed through this e coli determination. Even though the concentration is less than the permissible value in Porur lake (L2) there is some higher value of Ecoli which needs further investigation and direct consumption of that water should be prevented. Presence of E coli in various lakes is shown in the Fig.-8.

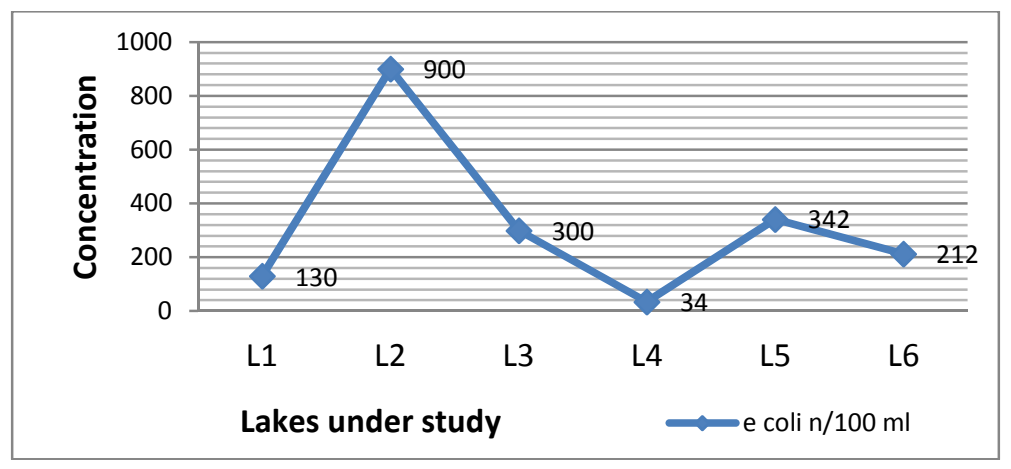

Fig.-8: The concentration of e coli in the Lakes

\section{Water Quality Index (WQI)}

In this study WQI has been calculated using the standards of surface water quality recommended by World Health Organization (WHO), Bureau of Indian Standards (BIS) and EPA surface water quality. The weighted arithmetic index method ${ }^{2}$ has been used for the calculation of WQI of the waterbody. Table-3 shows the status of the lakes according to the index. The water quality index was calculated for all the selected lakes and the statuses of the lakes were examined. The results are shown in Table- 4 . The status of the Perungudilake (L1) has been arrived as good. The status Porurlake(L2) and Puzhal lake(L3) have been arrived as excellent. The status of the karapakkamlake (L4) and Velachery lake(L5) are labeled as very poor. The lake Nandhivaram gets the status of 'poor'.

Table-3: Water Quality Index (WQI) and status of water quality ${ }^{3}$

\begin{tabular}{c|c}
\hline Water Quality Index & Water quality status \\
\hline $0-25$ & Excellent \\
\hline $26-50$ & Good \\
\hline $51-75$ & Poor \\
\hline $76-100$ & Very Poor \\
\hline$>100$ & Unsuitable for drinking \\
\hline
\end{tabular}

Table-4: WQI Value and the Status of the Lakes under Study

\begin{tabular}{c|c|c}
\hline Lakes & WQI & Status \\
\hline L1 & 26.8726 .87 & Good \\
\hline L2 & 21.0721 .07 & Excellent \\
\hline L3 & 21.0521 .05 & Excellent \\
\hline L4 & 89.789 .7 & Very poor \\
\hline L5 & 94.4394 .43 & Very poor \\
\hline L6 & 53.6753 .67 & Poor \\
\hline
\end{tabular}

\section{CONCLUSION}

The results obtained from the quality analysis affirm that the water quality of Velachery Lake may not be suitable for domestic purposes. Disposing industrial wastewater into lake system has increased the 
chances of strong localized pollution and threat to the environment. The present study on the status of lakes around Chennai will help to assess the degree of treatment required for establishing water treatment plants in future. The high concentration of $\mathrm{pH}$, COD, TDS found in the Velachery Lake is much higher than the prescribed standard limit. The pollution level of the lake is increasing sharply and can cause a serious problem in the near future if not monitored and controlled. From this study, it can be concluded that surface water quality of the major lakes in Chennai city, is posing threat to ecosystem though some parameters are within desirable limits the rapid urbanization and industrialization can accelerate water pollution in the near future. Degrading water resources and the environment ultimately reduces the quality of life.

\section{REFERENCES}

1. APHA (American Public Health Association) (2005), Standards Methods for the Examination of Water and Wastewater, 21st edn., American Public Health Association, Washington DC

2. R. M. Brown, N. I. McClelland, R. A. Deininger and M. F. O. Connor, Water Quality IndexCrashing, The Psychological Barrier, Proc. 6th Annual Conference, Advances in Water Pollution Research, 1972, pp 787-794, DOI: 10.1016/b978-0-08-017005-3.50067-0

3. C. Chatterjee and M. Raziuddin, Environment and Pollution Technology, 1(2), 181(2002)

4. S. R. Carpenter, N.F. Caraco, D.L. Correll, R.W. Howarth, A.N. Sharpley, V.H. Smith, Ecol. Appl., 8(3), 559 (1998)

5. Gorde et al., Int. Journal of Engineering Research and Applications, 3(6), 2029 (2013)

6. H. P. Jarvie, B. A. Whitton, C. Neal, Sci. Total Environ., 210-211, 79(1998).

7. Joshua Nizel Halder, Nazrul Islam Journal of Environment and Human, 2(1), 2373 (2015)

8. EPA Environmental Protection Agency, Ireland 2011 'Parameters of Water Quality- Interpretations and Standards.

9. Ministry of Environmental Protection, China, Ceneral Administration of Quality Supervision and Quarantine (2002) Environmental Quality Standards for Surface water. GB3838-2002.

10. P. B. Rokade, R. M. Ganeshwade, Journal of Zoology, 25(2), 219(2005).

11. Water Quality Standards for Surface Water Sources as per CPCB (New Delhi), 2005.

12. D. Voutsa, G. Zachariadis, C. Samara, Th. Kouimtzis, J. Environ. Sci. Health, A30 (1), 1(1995).

13. B. A. Wiggins, R. W. Andrews, R.A.Conway, C.L. Corr, E. J. Dubratz, D. P. Dongherty, J. R. Eggard, S. Knupp, M. C. Limjoco, J. M. Mettenburg, J. M. Rinehardt, J. Sonsino, R. E. Torrijos, M. E. Zimmerman, Appl. Environ. Microbiol., 65, 3483 (1999).

14. Xiaohui Zhu, Yong Yue, Prudence W. H. Wong , Yixin Zhang and Jianhong Tan, Journal of Environmental Research and Public Health.,15, 195(2018), DOI: 10.3390/ijerph15020195

[RJC-2005/2017] 